\title{
Pembuatan Jig pengasah Pahat Bubut dengan Memanfaatkan Motor Pompa Air
}

\author{
Basuki Rachmat \\ J1. Grafika No. 2, Kampus UGM, Sinduadi, Mlati, Sinduadi, Mlati, Sleman, \\ Yogyakarta 55284 \\ Departemen Teknik Mesin dan Industri FT UGM \\ basukirachmat@ugm.ac.id)
}

\begin{abstract}
ABSTRAK
Alat bantu untuk mengasah alat potong (pahat bubut HSS) diperlukan guna memperlancar berjalannya praktik proses manufaktur ketika pahat sudah aus. Untuk efisiensi dan memanfaatkan peralatan yang dimiliki Laboratorium maka pembuatan dudukan jig pengasah alat potong dibuat menggunakan mesin bubut maximat emco V13, mesin milling emco F3, dan mesin las listrik. batu gerinda yang dihubungkan dengan motor pompa Air (yang telah dimodivikasi) digunakan dalam mengasah alat potong. Pengasahan pahat akan disesuaikan dengan teori yang ada dan hasil alat potong iris yang diasah akan dibandingkan dengan berbagai variasi kecepatan potong (feedrate) kemudian didapatkan data kekasaran permukaan benda dalam proses manufaktur material aluminum cor.

Hasil perbandingan uji kekasaran yang didapat ditampilkan dalam grafik print dari mesin uji ataupun input data ke Excel, apabila terjadi penyimpangan yang tipis dengan pahat bubut yang diasah oleh pabrikan (pahat baru) maka bisa dijadikan indikasi keberhasilan pembuatan alat bantu pengasah yang berarti terjadi penghematan waktu dan biaya.
\end{abstract}

Kata kunci: jig pengasah, gerinda

\section{PENDAHULUAN}

Proses Pelaksanaan praktikum

Proses Produksi / manufaktur menggunakan mesin bubut konvensional memakai alat pahat HSS yang siap digunakan, sedangkan untuk proses pengasahan pahat dengan jumlah yang banyak diperlukan alat bantu supaya pengasahan dapat cepat dan hasilnya sama antara pahat satu dan lainnya.

Pembuatan jig / dudukan pengasah ini adalah pengembangan jig untuk mengasah pahat bubut HSS yang telah ada dipasaran, hanya saja dibuat jig yang sederhana sesuai kebutuhan dapat ditentukan sudut putarnya pada masing-masing sumbu sehingga menghasilkan sudut potong, sudut buang dan sudut bebas sesuai ketentuan yang ada dan untuk pengasahan alat potong utama HSS ini sangat mendukung berjalanya praktikum.
Mesin gerinda adalah salah satu mesin perkakas yang digunakan untuk mengasah/memotong ataupun menggerus benda kerja dengan tujuan atau kebutuhan tertentu. Prinsip kerja mesin gerinda adalah batu gerinda berputar bersentuhan dengan benda kerja dalam hal ini pahat bubut sehingga terjadi pengikisan, penajaman, pengasahan, atau pemotongan. maka didapatkan :

1. Efisiensi dan dalam rangka pemanfaatan mesin dan peralatan Laboratorium yang dimiliki maka perlu dilakukan pemetaan dalam pembuatan Jig.

2. Karena pentingnya alat iris HSS tersebut pada kegiatan belajar mengajar khususnya praktikum, maka pembuatan Jig untuk pengasahan alat iris sangat bermanfaat untuk menajamkan kembali 
pahat sudah tidak tajam lagi dengan cepat.

Rumusan masalah yang penulis pakai antara lain dengan menampilkan Desain produk dari bentuk Jig dan komponen lainya disimulasikan dengan software, setelah sesuai maka diproses menjadi komponen nyata dan dirakit. Serta melakukan Unjuk kerja alat pengasah yang dibuat pada matral uji kemudian dilakukan Pengujian kekasaran dari tool hasil pengasahan.

Tujuan dari penelitian ini adalah dengan peralatan Laboratorium yang dimiliki dapat membuat komponenkomponen dari jig sesuai dengan fungsinya, serta dapat terus mengembangkan alat yang ada sehingga menjadikan pendukung optimalnya peralataan lain yang ada di laboratorium. Manfaat lain yang diharapkan dari penelitian adalah alat ini bisa digunakan sebagai pendukung Proses Praktikum, penelitian ataupun proyek untuk pengembangan.

\section{METODE PENELITIAN}

\section{Obyek Penelitian}

Membuat 1 unit Mesin Pengasah Pahat Bubut HSS. Membuat benda uji menggunakan Mesin bubut Emco Maximat V-13 dengan 2 tools untuk dibandingkan hasil penyayatannya. 1 pahat masih baru keluaran Pabrik dan yang sudah diasah dengan mesin yang dibuat. Data uji kekasaran permukaan

Prosedur Penelitian yang dilakukan adalah:

Merancang dan mendesain komponenkomponen mesin gerinda yang dapat berfungsi mengasah pahat bubut dengan hasil pengasahan yang bagus dan dapat dipertanggung jawabkan dengan data. Mencari produk / komponen yang tersedia di pasaran. Memilih material dan teknik produksi komponen. Mengevaluasi produk dilakukan pada proses perencanaan produk. Merakit semua komponen. Digunakan mengasah pahat bubut HSS untuk tool uji. Pahat yang baru dan yang telah diasah dipasang pada toolhoder MaximatV13. Menggunakan mesin bubut Emco Maximat V13 untuk membuat material Aluminium Cor dari 2 alat iris tersebut ketebalan penyayatan $1 \mathrm{~mm}$

Data A / a Spindle speed $1500 \mathrm{rpm}$ dengan Feedrate $50 \mathrm{~mm} /$ menit

Data B / b Spindle speed $1500 \mathrm{rpm}$ dengan Feedrate $75 \mathrm{~mm} /$ menit

Data C / c Spindle speed $1500 \mathrm{rpm}$ dengan Feedrate 100 mm/menit

Tool baru A

Tool yang diasah a

Material uji tersebut di bawa ke Lab. Bahan untuk diuji masing-masing mempunyai data uji kekasaranya dan dibandingkan data yang didapatkan. Membuat laporan dan analisa.

\section{Teknik Analisa Data}

Teknik pengambilan data dilaksanakan diawali dengan desain dan disimulasikan menggunakan software Autodesk Inventor untuk mengetahui beban dan daya yang akan ditopang pada mesin yang dibuat data yang didapat pada simulasi menjadi rancangan mesin yang aman, berfungsi efektif dan efisien. Proses selanjutnya pembuatan komponen dan merakit sekaligus mencoba fungsinya yaitu mengasah pahat bubut. Yang kemudian digunakan untuk penyayatan material Aluminium cor. Dari hasil penyayatan ini diharapkan mendapat hasil penyayatan yang mendekati atau hampir sama dibandingkan dengan yang alat iris yang baru (orisinil pengasahan dari pabrik).

\section{HASIL DAN PEMBAHASAN \\ Pembuatan Jig Pengasah Pahat Bubut HSS}

1. Pompa Air (dimodivikasi)

Digunakan motor pompa air MOSWELL MW-125 sebagai motor untuk memutar batu gerida yang disambungkan dengan as.

Dengan melepas rumah dan dudukan impeler yang ada digantikan dengan as penghubung

Spesifikasi Berat $5,35 \mathrm{~kg}$

Daya output Listrik 200 Watt 


$\begin{array}{ll}\text { Daya Input Start } & 450 \text { Watt } \\ \text { Daya Hisap } & 9 \text { meter }(\max ) \\ \text { Daya Dorong } & 30 \text { meter }(\max ) \\ \text { Total Head } & 39 \text { meter } \\ \text { Debit Air } & 54 \text { l/menit (max) } \\ \text { Inlet } & 1 \text { inch } \\ \text { Outlet } & 1 \text { inch }\end{array}$

\section{Batu Gerinda}

Sebagai mana namanya batu gerida ini digunakan mengikis, mengasah atau menajamkan permukaan pahat HSS dan hanya memerlukan sedikit gesekan dibidang-bidang tertentu. Dibuatkan dudukan pemegang sekaligus menerima transmisi dari modivikasi mesin pompa air.

Spesifikasi NORTON

Max 35m/sec NVBE TIC 5x5/8x1/2 “ P0016660, J522044

\section{Jig Pemegang bagian bawah}

Dibuat menggunakan matreal mildsteel pertimbangannya tidak tekena beban yang berat sebagai pengatur sudut bagian bawah berputar ke kiri dan kanan total sudut yang dapt ditempuh $180{ }^{\circ} \mathrm{C}$ dan sebagai penyangga Jig atas.

\section{Jig atas}

Berfungsi untuk memegang pahat HSS yang akan diasah berputarnya ke atas dan ke bawah total sudut yang dapat ditempuh $90{ }^{\circ} \mathrm{C}$.

\section{Meja eretan}

Meja ini berfungsi menggeser ke posisi penyayatan, apabila sudut bagian bawah dan sudut bagian atas sudah sesuai maka fungsi kerja meja eretan yang digerakkan maju dan mundur(posisi melintang).
Sedang untuk kedalaman/ketebalan maka meja bisa digeser kesamping kiri dan kanan (posisi memanjang)

\section{Pengasahan Pahat Bubut}

Setelah semua komponen jadi diproduksi kemudian dirakit menjadi alat bantu pengasah pahat bubut HSS yang sederhana dan murah dapat digunakan untuk mengasah berbagai bentuk pahat dan harus diuji hasil pengasahannya diselaraskan dengan teori pengasahan yang ada kemudian dibandingkan dengan beberapa Variasi kecepatan Potong (Feedrate)

Langkah pengasahan yang harus dilakukan :

1. Pastikan Batu gerinda asah terpasang dengan benar dan kuat

Pasang Pahat HSS yang akan diasah pada jig bagian atas dan bagian bawah diseting sesuai teori yang ada dengan sudut potong $80{ }^{\circ} \mathrm{C}$, sudut buang sisi samping $12-15^{\circ} \mathrm{C}$. di putar posisi pahat sudut bebas tatal $12-20{ }^{\circ} \mathrm{C}$.

Penampang 1

2. On kan motor dan disayatkan perlahan maju, pada satu permukaan pada 2 sudut yang dipadukan, sampai 1 permukaan rata tecapai.

Diputar pahat HSS yang terpasang yaitu dengan melepas dan memutar kemudian menyesuiakan seting pada sudut berikutnya. Sudut bebas muka $8-10^{\circ} \mathrm{C}$, sudut bebas samping $10-20{ }^{\circ} \mathrm{C}$. Penampang 2 dan 3

3. On kan kembali motor dan disayatkan perlahan maju, pada satu permukaan pada 2 sudut yang dipadukan, sampai 1 permukaan rata tecapai.

4. Proses Pengasahan Pahat HSS selesai 


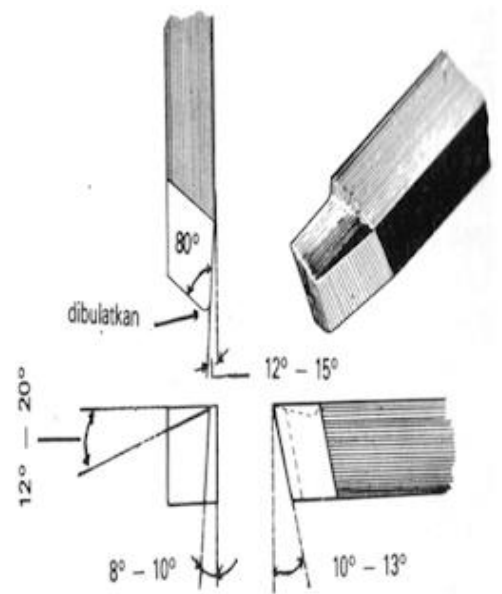

Gambar 1. Posisi Pahat

Proses penyayatan pada material Aluminium Cor

Menggunakan Mesin Emco Maximat V13 diseting semi otomatis, material Aluminium Cor dengan ketebalan sayat 1
A
a $\quad 50 \mathrm{~mm} /$ menit

B

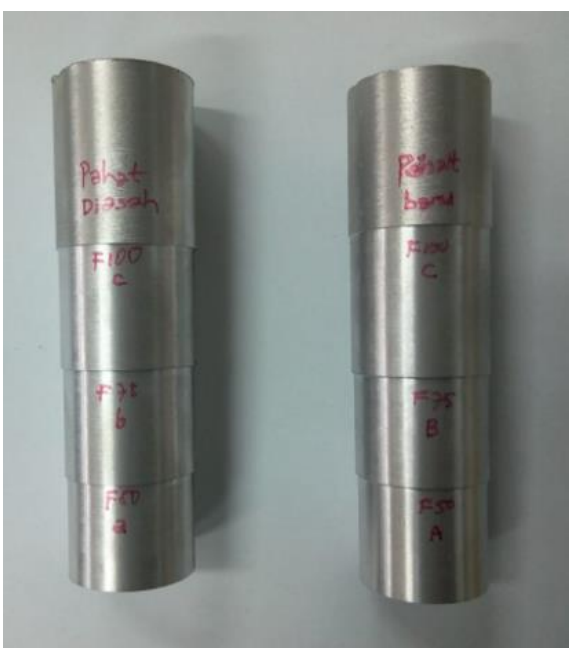

Gambar 2a mm Spindle Speed $1500 \mathrm{rpm}$ dengan variasi Feedrate nya masing-masing :

C $\quad$ c $\quad 100 \mathrm{~mm} /$ menit

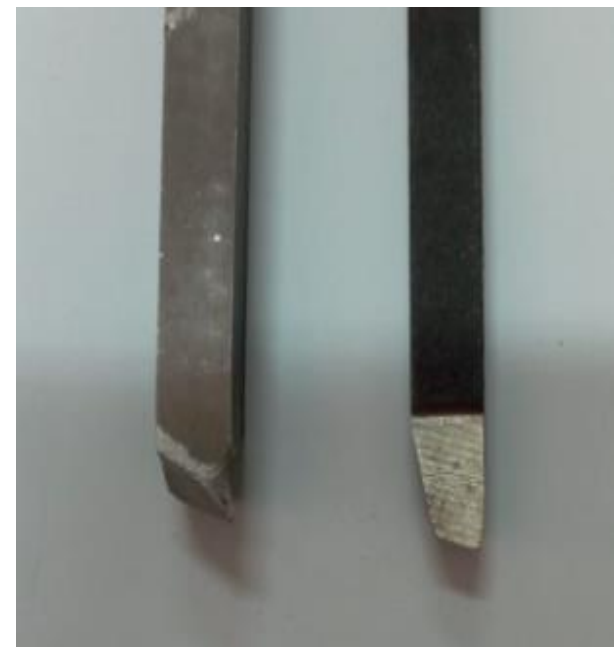

Gambar 2b

Gambar 2a. Hasil penyayatan pada material Alumunium cor menggunakan (2b) Pahat bubut HSS yang baru dan Hasil penyayatan pada material Alumunium cor menggunakan Pahat bubut HSS yang telah diasah

\section{Pengujian Kekasaran}

Masing-masing material diuji kekasarannya menggunakan mesin Surfcom 120A ketelitian kekasaran dalam ukuran satuan Mikrometer.

Tabel 1. Tabel Ra Menggunakan Spindle speed $1500 \mathrm{rpm}$ dan Feedrate dalam mm/menit

$\begin{array}{lllllll}\text { Feed } & \text { A } & \text { a } & \text { B } & \text { b } & \text { C } & \text { c }\end{array}$




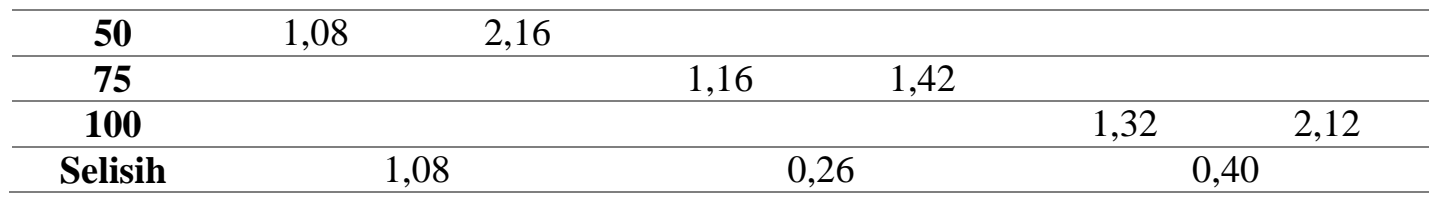

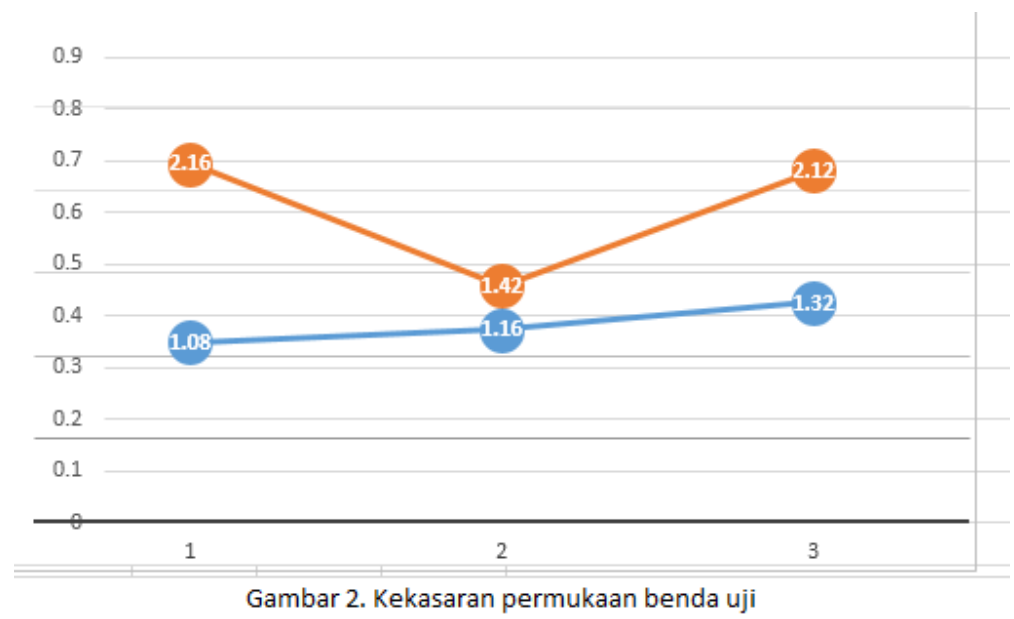

Gambar 3. Hasil Cetakan dari Mesin uji kekasaran satuan dalam Mikrometer Alat iris Baru

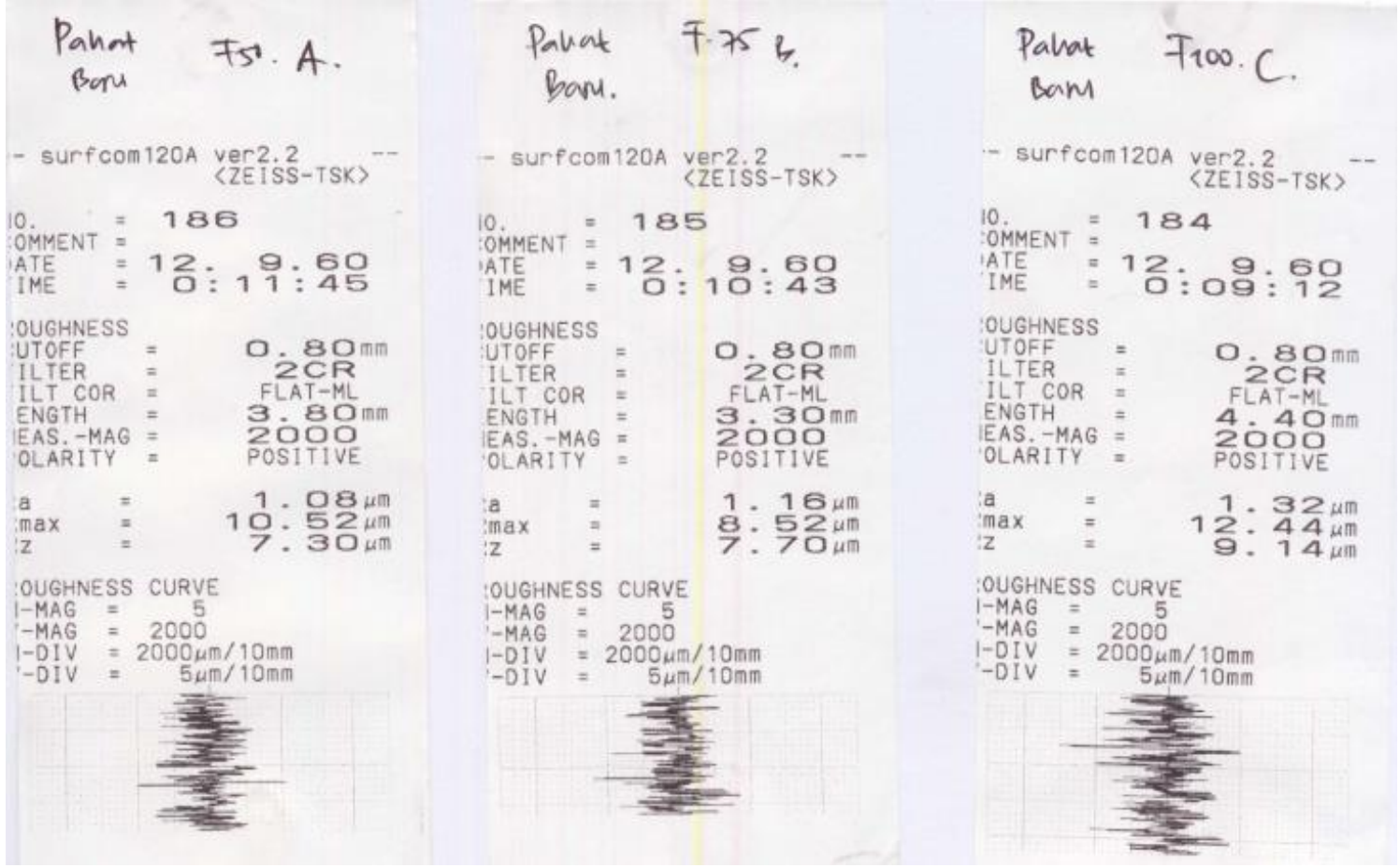

Gambar 4. Hasil Cetakan dari Mesin uji kekasaran satuan dalam Mikrometer Alat iris yang diasah 


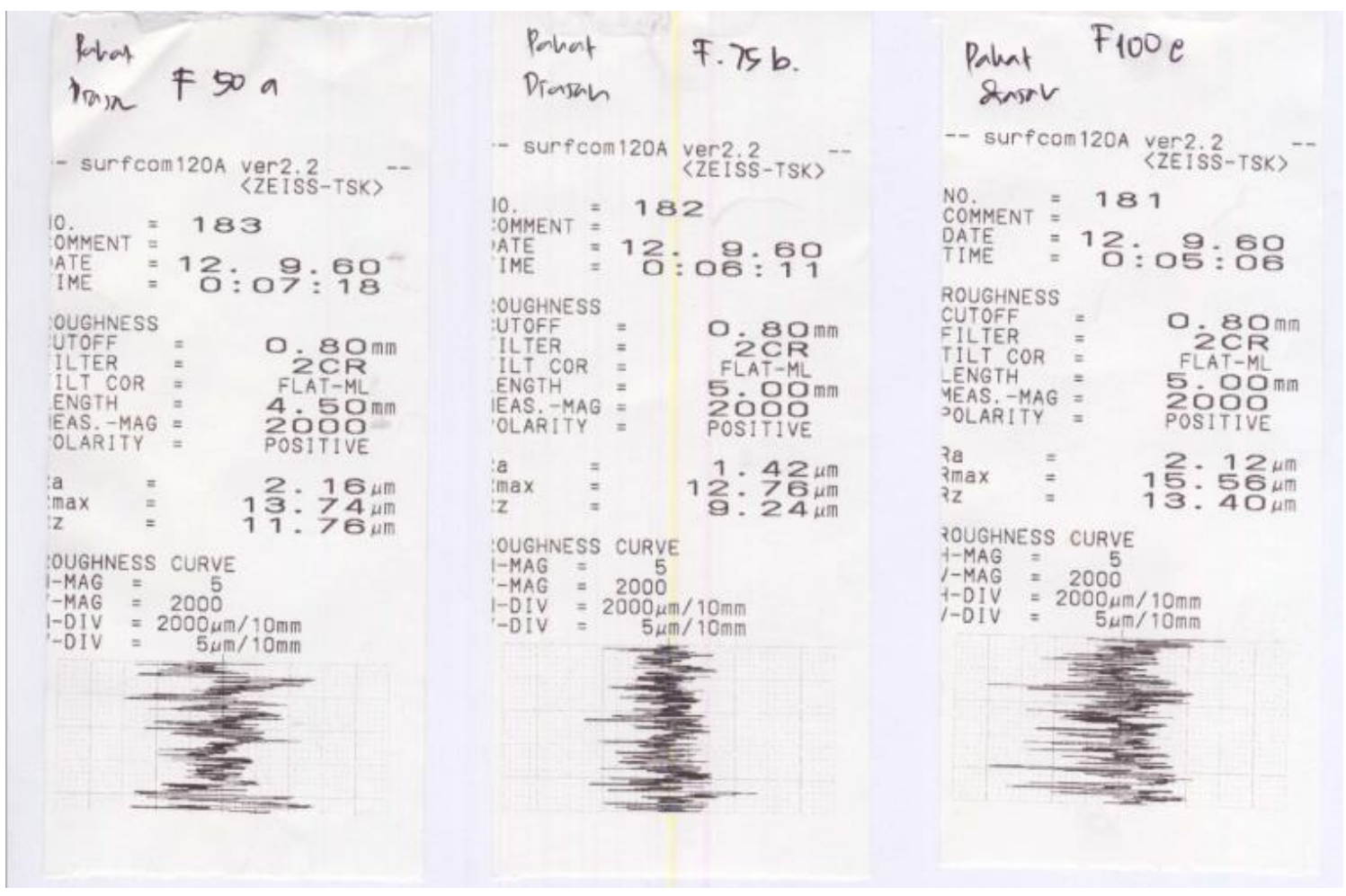

Gambar 5. Pembuatan Jig pengasah Pahat Bubut dengan Memanfaatkan Motor Pompa Air

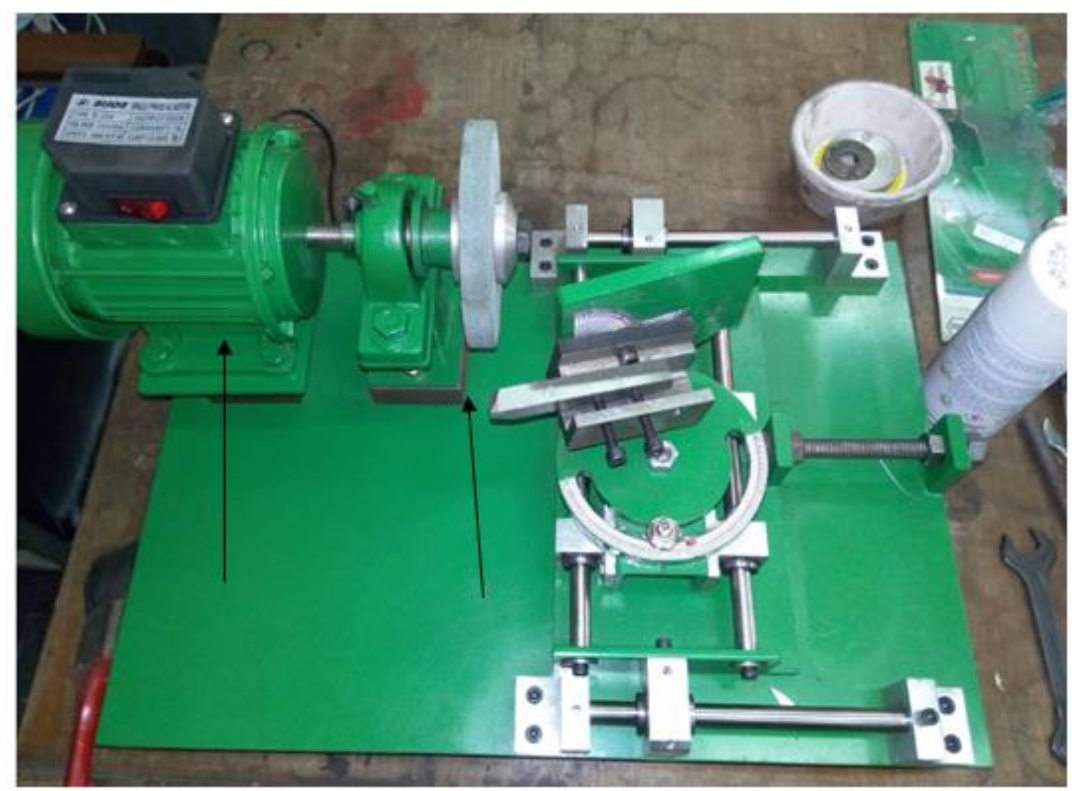

Gambar 6. Pengasah Pahat Bubut dari Pompa

\section{KESIMPULAN}

Optimalisasi peralatan laboratorium dapat terlaksana. Ketrampilan semakin terasah dengan peralatan yang dimiliki.
Pembuatan part pendukung mudah dan murah termasuk efisiensi. Sesuai fungsi dan kebutuhan. Memungkinkan untuk diperbaiki dan dikembangkan . 


\section{DAFTAR PUSTAKA}

Assauri, Sofyan, 2004, Manajemen Produksi dan Operasi, edisi revisi, Lembaga Penerbitan FE UI, Jakarta

Darmawan H., 2004, Pengantar Perancangan Teknik, Direktorat Jendral Pendidikan Tinggi; Jakarta
Sularso Kiyokatsu Suga K., 2004, Dasar Perencanaan dan Pemilihan Elemen Mesin. Jakarta : Pradnya Paramita

Petunjuk Penggunaan Mesin Bubut Emco Maximat V-13, 1988 Emco Maier \& CO, Friedmann-Maier, Austria

Petunjuk Penggunaan Mesin Milling Emco F-13, 1988 Emco Maier \& CO, Friedmann-Maier,
Austria 